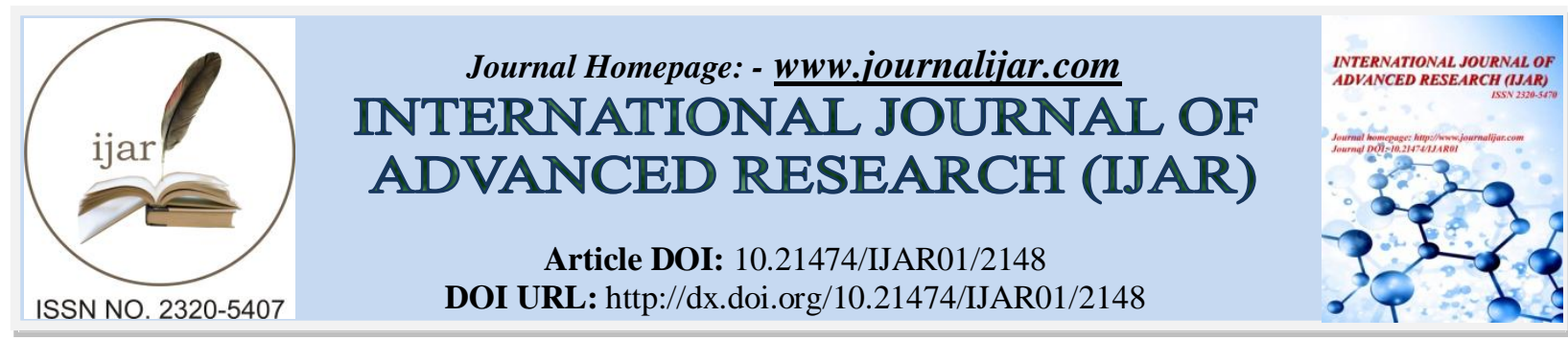

RESEARCH ARTICLE

\title{
A STUDY TO ASSESS THE KNOWLEDGE ON PREVENTION AND CONTROL OF DENGUE FEVER AMONGTHE MOTHERS OF UNDER FIVE CHILDREN AT KARAIKAL MEDU VILLAGE, KARAIKAL.
}

Prof. Mrs. R. Joseph Hermaline M.Sc., (N), Ph.D. Vice Principal, Vinayaka Mission's College of Nursing, Karaikal, Puducherry State.

\section{Manuscript Info} .......................... Manuscript History

Received: 25 September 2016 Final Accepted: 27 October 2016 Published: November 2016

\section{Abstract}

Dengue fever viruses is considered the most important arbo viruses in terms of morbidity, mortality and economic cost with in estimated 100 million cases of dengue fever occurring throughout the world annually. A study to assess the knowledge on prevention and control of dengue fever among the mothers of under five children at karaikalmedu village, karaikal was conducted among 30 mothers of under five children. The study showed that majority $20(66.7 \%)$ had inadequate level of knowledge, 9(30\%)had moderate level of knowledge and one (3.3\%)had adequate level of knowledge. There was a significant association between knowledge regarding prevention and control of dengue fever with selected demographic variables such as age, education, occupation, religion, place of living and sources of information.

Copy Right, IJAR, 2016,. All rights reserved.

\section{Introduction:-}

Dengue fever is an febrile viral diseases characterized by sudden onset, fever on three to five days. Dengue virus are flaviviruses and include four serotypes one, two, three and four. These viruses also responsible for dengue hemorrhagic fever (DHF). The viruses are transmitted to man by bite of infective mosquitoes, mainly Aedes egypti. Dengue fever viruses is considered the most important arbo viruses in terms of morbidity, mortality and economic cost with in estimated 100 million cases of dengue fever occurring throughout the world annually. These includes fever, a maculopapular rashes and headache, primary infection with dengue usually results in a febrile, self limitating diseases, however secondary infection may results in severe complication such as dengue shock syndrome (DSS) or dengue hemorrhagic fever (DHF).

The incubation is 4 to 7 days (range 3-4) days. This disease is now endemic in most tropical and sub-tropical countries DHF caused by the same viruses, is characterized by increased vascular permeability, hypovolemia and abnormal blood clotting mechanism. Patient diagnosed with dengue endemic area such as south east Asia generally have secondary infection. Characteristic antibody response to the diseases enable serological diagnosis and differentiation between primary and secondary dengue.

The viral etiology and the transmission by mosquito were only deciphered in the $20^{\text {th }}$ century. The socio-economic impact of world war II resulted in increased spread globally.Now a days about 2.5 billion people or $40 \%$ if the world's population, live in areas where there is a risk of dengue transmission. Dengue fever to more than 100 countries in Asia, Pacific, America, Africa. The carribean and India etc. 


\section{Need For The Study:-}

Dengue has become a serious health problem world and scientists are focusing their attention on understanding how the dengue virus causes disease. Basic research includes a wide range of studies focused on learning how to dengue virus is transmitted and this type of research investigates many aspects of dengue viral biology, including exploration of the interaction virus and studies of how dengue virus replicate itself. The last 3 years have not been good for the state in terms of dengue evidence. In 2011 the number of cases 2,501 and in 2010 was 2051. The state seems to have manged to control the number of deaths up continue this year with 8 in 2010 and 9 in 2011. Given the ratio of dengue cases to the number of fever cases, of appears dengue is in alarming proportions in the three south states of Tamilnadu, Kerala and Karnataka. In Tamilnadu total of 5,376 of dengue fever. The highest rate og dengue fever in the country this year. Professional figures listed on the website of the National vector-Borne disease control programme the union recorded 39 deaths from dengue in 2013 the highest again.

All the above statistics and suggestion are concluded that the under five children are prone to get dengue fever. If it is not treated at proper time it may result serious problem even death also hence the investigator is interested to conduct the study among the mothers of under five children and the present study has been design to assess the prevention and control of dengue fever.

\section{Statement Of The Problem:-}

A study to assess the knowledge on prevention and control of dengue fever among the mothers of under five children at karaikalmedu village, karaikal.

\section{Objectives:-}

1. To assess the knowledge on control and prevention of dengue fever among the mothers of under five children.

2. To find the association between knowledge on dengue fever among the mothers of under five children with selected demographic variables.

\section{Methodology:-}

The design used for this study was descriptive design. The study was conducted for mothers of under five children who are residing at karaikal medu, karaikal aged between 20 to 40 years. The sample size was 30 and the samples were selected using purposive sampling technique and with predetermined inclusion criteria. The Tool consists of two section: Section-I -It has items related to demographic variables such as age, religion, parents occupation, family income, type of family and sources of information. Section-II -It consists of Knowledge questionnaire regarding Prevention and control of dengue fever among mothers of under five children. After getting written permission from panchayat president in Karaikalmedu, village, informed oral consent was obtained from the study participants. Data was collected from mothers of under five children. Self structured questionnaire was administered to each mother separately and data was collected on the same day from all the participants

\section{Result and discussion:-}

The results of the study revealed that $26 \%$ of the sample were in the age group of $25-30$ years. $46 \%$ were got secondary education, $43 \%$ belongs to self employee, $70 \%$ mothers were belongs to muslim, $90 \%$ belongs to both vegetarian and non-vegetarian, $40 \%$ were got information from mass media. 


\section{FIG 4.1:DISTRIBUTION OF SAMPLES ACCORDING TO THE LEVEL OF KNOWLEDGE}

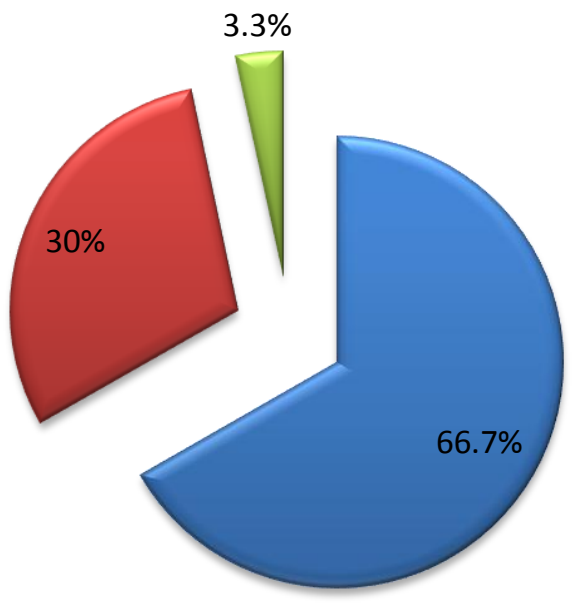

In adequate

Moderate

adequate

Fig - Level of knowledge regarding on prevention and control of dengue fever among mothers of under five children.

The study result indicates that only 20(3.3\%) had adequate knowledge, 9(30\%) had moderate level of knowledge, and one (66.7\%) had inadequate knowledge. The present study reveals that there was significant association with demographic variables .

\section{Conclusion:-}

The knowledge of people regarding preventing and control aspects of dengue fever was inadequate $(<50 \%)$. This indicates the necessity of an improvement in the economic and socio cultural status of the community and promotion of health.

\section{Recommendations:-}

- A similar study can be conducted in the large samples for better generalization.

- Experimental study can be done to assess the knowledge and practice.

- Comparative study can be done in rural and urban areas.

\section{References - Book References}

1. Anitha Collins (2008), "Medical Surgical Nursing II" $1^{\text {st }}$ edition, Frontline Publication, Page No:543-552.

2. Basavanthappa BT (2013), "Community Health Nursing" $4^{\text {th }}$ edition, Jaypee Publication, Page No: 502-510

3. Kulkarni A.P. (2002), "Community Medicine" $2^{\text {nd }}$ Edition, Vora Medical Publication, Page No:.413

4. Park.K (2013), "Preventive and Social Medicine", $22^{\text {nd }}$ edition, Banarsidas Bhanot Publication, Page No:224 231

5. Polit BF, Bech(2008), CT “Nursing Research ; generating and assessing guidance for Nursing Practice”, $8^{\text {th }}$ edition, New Delhi : Wolters Kluwer Publication, Page No: 76, 89. 